\title{
Entrenchment Effect and Audit Quality in Family Business of Pakistan
}

\author{
Safdar Husain TAHIR ${ }^{1}$, Sadaf AKRAM², Shahida PERVEEN³, Gulzar AHMAD ${ }^{4}$, Muhammad Rizwan ULLAH ${ }^{5}$
}

Received: March 14, 2020 Revised: May 17, 2020 Accepted: July 07, 2020

\begin{abstract}
The purpose of this study is to test both the alignment theory and entertainment theory on family firms listed on the Pakistan Stock Exchange. To achieve these goals, we collected secondary data from 164 non-financial family firms in various sectors during $2014-18$. These family firms are classified into two categories: family control firms and family owned firms. We take the audit fee and the audit quality as dependent variables while family control firms, family-owned firms, and family CEOs as independent variables. In addition, the study uses leverage, profit and export as control variables. To test the effect of the explanatory variables on the output variables, we use two econometric models, Ordinary Least Square and the Probit regression model. In addition, Huber Sandwich test is used to check the nonnormality and heteroscedasticity of panel data. Contrary to the alignment effect, the study supports the entrenchment effect and advocates that family-controlled firms as well as family-owned firms are not conscientious regarding the selection of external auditors during their contracts with audit firms. They are less likely to pay high audit fees for good quality audit in Pakistan. Furthermore, the study shows a statistically significant and positive relationship between audit quality and audit fees.
\end{abstract}

Keywords: Alignment Effect, Family Firms, Entrenchment Effect, Audit Quality, Audit Fee

JEL Classification Code: G41, M1, M4, M42

\section{Introduction}

Nowadays, family firms (FFs) are growing rapidly, especially in developing countries. In Asian countries, FFs account for $32 \%$ of the total market capitalization (Wang, 2006) FFs account for $49 \%$ of market capitalization in Southeast Asia. In Pakistan, FFs are the backbone of the economy accounting for $80 \%$ of market capitalization

${ }^{1}$ First Author and Corresponding Author. Associate Professor, Lyallpur Business School, Government College University, Faisalabad, Pakistan [Postal Address: Officer Colony-2, Madina Town, Faisalabad, 38860, Pakistan] Email: drsafdargcuf@gmail.com

'2Lecturer, Department of Business Administration, Government College Women University, Faisalabad, Pakistan. Email: sadafakram62@yahoo.com

${ }^{3}$ Assistant Professor, Department of Business Administration, Government College Women University, Faisalabad, Pakistan. Email: shahidanaeem2@gmail.com

${ }^{4}$ Professor, Department of Psychology, Lahore Garrison University, Lahore, Pakistan. Email: gulzar818@gmail.com

${ }^{5} \mathrm{PhD}$ Scholar, Lyallpur Business School, Government College University, Faisalabad, Pakistan. Email: mrizwanullah77@gmail.com

(c) Copyright: The Author(s)

This is an Open Access article distributed under the terms of the Creative Commons Attribution Non-Commercial License (http://Creativecommons.org/licenses/by-nc/4.0/) which permits unrestricted noncommercial use, distribution, and reproduction in any medium, provided the original work is properly cited.
(Pakistan Bureau of Statistics, 2017-18). Instead of conducting extensive research on FFs around the world, some of these areas need to be examined in the context of alignment and entrenchment theories, especially in Pakistan. The current research finds a gap in the literature of FFs and helps to investigate the conduct of family firms regarding quality of audit and audit fees.

The agency's problem is exacerbated when corporate managers ignore shareholders' interests in the strategic decision-making process. The agency theory argues that management is self-made and seeks to maximize its wealth at the expense of shareholders (Jensen \& Meckling, 1976). Experimental investigations support the correlation between agency conflicts and information asymmetric,and signals that regulators seek to combine financial data to maximize their personal compensation in the firm's shares (Mitra, Hussein and Des, 2007). In such cases, a system of governance is required that can monitor the conduct of managers and protect the rights of shareholders (Karim, 2010). Previous studies on audit fees (AF) and audit quality (AQ) offer two scenarios. First, due to less conflict of interest between owners and managers, FFs expect less demand and ultimately pay less (Ho \& Kong, 2013). Second, the offer of higher privileges and bonuses in the FFs may increase fraudulent activity, which further increase the risk of audit (Casino, Puglisi, 
Mussolini and Sansone, 2010). In order to eliminate the risks of audit, auditors will have to conduct audits that can receive relatively more $\mathrm{AF}$. The existence of such conflicting views makes $\mathrm{AF}$ and $\mathrm{AQ}$ an interesting topic in FFs.

The demand for audited financial reports in Pakistan's audit market is low, and there is little concern about the quality of audits (Subhan \& Werner, 2003). Currently, there are three types of audit firms operating in Pakistan: local audit firms, Big Four-affiliated firms, and Big Four firms. The Big Four audit firms outperform their counterparts. Siddique, Zaman and Khan (2013) have revealed that firms affiliated with the Big Four are earning less AF than the Big Four companies, which shows that,for the firms affiliated with the Big Four and the Big Four firms, the AQ is not the same. The presence of this different criterion gives a new dimension to this research. The present study bridges this gap and contributes to the existing FF literature in Pakistan.

The textile industry in Pakistan is a major exporter accounting for $57 \%$ of the country's total exports. Exports of the textile sector increased to $\$ 13.53$ billion in 2018, from $\$ 12.45$ billion in the previous period. (Pakistan Bureau of Statistics, 2017-18). Many FFs working in Pakistan's textile sector supply chain to various international brands. In the textile sector, foreign buyers play a significant role as major stakeholders. These foreign investors are always very concerned about the audit of companies. Past studies (Khan, Matkeen and Siddiqui, 2013; Islam and Deegan, 2008) identify pressure groups questioning the financial disclosure of these key foreign buyers. It is believed that these buyers are concerned about AQ in Pakistan. Ashbaugih and Warfeld (2003) stated that foreign buyers generally prefer offering audit services to auditors. In the context of Pakistan, the decision to hire a quality auditor depends on the firm's reputation for its quality of audit services; it reduces some of the anxiety about the quality of financial statements. Thus, the present study provides valuable information to FF's decision-makers to formulate their strategies and attract foreign investors to Pakistan, which is an important component of the economy.

In the context of FF, there is an important concept of family-ownership theory, the entertainment effect (Wang, 2006). This effect shows that large shareholders have higher privileges to seize the wealth of other shareholders. This suggests that family ownership is linked to the provision of income earnings (Grass, 2013). Frances (2004) discovered that economies with weak legal frameworks generally have a lower demand for standard audits. In emerging economies such as Pakistan, the FFs have less demand for audit standards, which makes the study more interesting. Contrary to the entrenchment effect, the alignment effect makes it clear that family ownership creates strong oversight by controlling firm owners. According to this effect, FFs are more likely to potentially sacrifice short-term benefits for future business generations and protect the family's reputation (Imam and Malik, 2007). Previous studies such as Chaney, Jeter \& Shivakumar (2004) and Ho \& Kang (2013) show the effect of family ownership on the quality of earnings and audit choices in developing countries. This study explores the effect of FCF and FOF on AF and AQ in the context of Pakistan.

The alignment theory argues that insider ownership of key executives such as directors or officers positively influences the performance of firms, resulting in an increase in the value of a firm. As the level of internal ownership increases, so does the value of the company. As the corollary, we could conclude that the top management of high-performing firms has a high level of ownership or involvement in the decisionmaking process. Contrary to the theory of alignment, the entertainment theory reveals that large ownership of key executives, employees and officers diminishes the value of companies. As key executives gain more power, it is argued, they use that power for personal gain to the detriment of the company.

From corporate managers to executives at the company, it is hard work to get a position. In order to maintain this position for a long time, they have to acquire as many shares as possible into their pockets. As a result, their ownership skyrockets. This registered executive will do what he thinks without fear of removal. Other stakeholders are unhappy with them and are willing to sell their shares. The share price starts to fall and eventually the value of the company starts to decline. The current study explores empirically what is happing in non-financial family firms of Pakistan.

The rest of the study is structured as follows: the second part summarizes the review of literature and makes assumptions, the third part contains data and methods, and the fourth part presents analysis and results. The last part of the study concludes.

\section{Literature Review and Hypotheses}

Chen, Yin, Fu and Chang (2007) find an indirect link between AQ and family-controlled firms (FCF). Leung and Wang (2010) investigate the association between AF, AQ and FCF using a sample of firms listed in Hong Kong. The results of their study show that FCF pays less AF, which is ultimately linked to lower AQ. Humayun and Hakimzada (2017) test AQ and AF in family-controlled companies. To this end, they collect data from family and non-familycontrolled companies for the period 2007-2014. Ho and Kang (2013) also investigate the value of family-majority firms. They reveal that family-controlled firms have less AQ and pay less AF. Nosheen and Chonglerttham (2013) analyze the influence of family ownership on the quality of the audit firm. Their search reveals that AQ has an inverse relationship with the compensation of family executives. 
They recommend adding non-family members to the corporate board to improve AQ. Khan et al. (2013) report that family executives are less likely to pay more AF in 500-Australian firms.

Shehzad, Shahnaz and Javed (2017) examine the impact of family-controlled firms (FCF) and AQ on firm performance (FP) using data from Pakistani-listed companies for the period 2007-04. Their study reveals a positive correlation between family control and AQ, which increases performance. Ghosh and Tang (2015) discover that FFs use external editors to pay less AF. Del Basco and Batinelli (2020) examine the impact of family-owned SMEs on foreign investment. Their study use two different aspects of ownership as full ownership and shared speculation. In addition, they use three types of distances among family members: institutional distance, geographical distance, and cultural distance. The results show that these distances have a special effect on the choice of ownership style. Further, the results show that the FCF cultural distance, institutionalized Strengthens the relationship between distance and foreign ownership. Some other studies, such as Al-Okaily (2020), show that FFs pay less AF than non-family companies. They further show that the FFs have to pay more AF during the crisis period. The mixed results of previous studies encourage us to investigate the relationship between FCF, FOF and AQ. Based on conclusions drawn from the above discussion, we suggest the first hypothesis of the study as:

H1:Family-controlled firms (FCFs) in Pakistan are less likely to pay higher audit fees for good quality audits.

Lee and Lam (2018) investigate the impact of ownership firms (FOF) on audit quality (AF) using panel data from firms listed in Hong Kong. He reveal that the FOF has a statistically significant negative impact on audit fee (AF). Similarly, Joshi, Al Ajmi and Bremser (2009) find a negative relationship between $\mathrm{AQ}$ and FOF. Yet another research in Bangladesh shows that publicly-listed FOF are less likely to pay higher AF (Khan, Matkeen and Siddiqui, 2015). In addition, they reveal that the FOF has a lower quality audit than other contemporary companies. Liu and Subramaniam (2013) also point to the negative correlation between FOF and AF, stating that companies with higher FO pay less AF.

Gaaya, Lakhal and Lakhal (2017) investigate the association between FOF and corporate tax avoidance (CTA). He also examined whether the audit quality (AQ) of family-owned firms (FOF) was affected by tax evasion. The results reveal a positive correlation between FOF and CTA. For this purpose, their study use data from 55 listed Tunisian firms during 2008-2013. In addition, the results show that $\mathrm{AQ}$ of FOF prohibits the inclusion of a combination of aggressive tax positions, which supports the moderate role of AQ in the relationship between FOFs and tax avoidance. Other studies such as Sarhan, Ntim and Al-Najjar (2019) show positive affiliation between MENA countries in terms of board size, director shareholdings, board independence and AF. The results of their study show that FOF levels have a negative impact on firms that pay exorbitant fees. This study does not show any specific relationship between FOF and AF. Yopie and Itan (2016) examine the influence of corporate governance $(\mathrm{CG})$ on the value of the FOF. The results show the negative impact of the family CEO on the value of the FOF. Due to the mixed results of the studies discussed above, we propose another hypothesis.

H2: Family-owned firms (FOFs) are less likely to pay higher audit fees to obtain good quality audits in Pakistan.

Rainsbury, Bradbury and Cahan (2009) analyze data from 87 New Zealand firms and investigate the effects of AQ on the external editor's AF. The results of their study show no effect of AF on AQ. In addition, it highlights the insignificant relationship between AQ and financial reporting standards. Some other studies examine the correlation between AQ and abnormal AF (Choi, Kim and Zhang, 2010). The abnormal AF defines the difference between actual AF paid and expected AF. The results show no significant relationship between AQ and AF. On the other hand, Mohammad Rezaei, Mohd-Saleh and Ahmed (2018) use the data of listed Iranian companies for the period 2006 to 2015 to review the association between audit firm ratings and their audit fees. Their study concludes that highly-ranked audit firms charge high AF as compared to lower-ranked firms. Similarly, Ahmed and Goyal (2005) claim that high quality auditors charge high AF. Results from the above studies propose a third hypothesis.

H3: There is a positive relationship between $A Q$ and $A F$ of external editors.

\section{Research Methodology}

This study examines the behavior regarding quality (AQ) of family firms (FFs). We classify FFs into two types - family-controlled firms (FCFs) and family-owned firms (FFs) - to review their approach to audit quality AQ and audit fees (AF). The FF data listed on the Pakistan Stock Exchange (PSX) is taken from their annual reports covering the period 2014-2018. The AF and AQ (FCF and FOF) of the study are regressed. In addition, the study also uses leverage, profit (PR) and exports (former) as control variables. Sample synthesis, and description and measurement of the study variable are shown in Tables 1 and 2, respectively. 
Table 1: Sample Composition

\begin{tabular}{|l|c|c|l|c|c|}
\hline \multicolumn{1}{|c|}{ Industry } & No. of Firms & \%age & \multicolumn{1}{c|}{ Industry } & No. of Firms & \%age \\
\hline Food & 17 & 10 & Energy & 11 & 07 \\
\hline Leather & 03 & 02 & Utilities & 04 & 02 \\
\hline Chemical & 17 & 10 & Sugar & 22 & 14 \\
\hline Oil and gas & 05 & 03 & Telecom & 03 & 02 \\
\hline Security paper & 06 & 03 & Textile & 25 & 17 \\
\hline Machinery and steel & 14 & 08 & Pharmaceutical & 06 & 03 \\
\hline Cement and building materials & 16 & 10 & Motor and Engineering & 15 & 09 \\
\hline Total Firms & 164 & & & & \\
\hline
\end{tabular}

Table 2: Variables Description

\begin{tabular}{|c|c|c|}
\hline Variables & Measurements & Reference \\
\hline \multicolumn{3}{|l|}{ Explained Variables } \\
\hline Audit Fee (AF) & $\begin{array}{l}\text { The fee which is paid by a firm for purchasing the services of a } \\
\text { certified auditor or any audit firm." }\end{array}$ & $\begin{array}{l}\text { Khan et al. (2015) } \\
\text { Ji and Yoon (2020) }\end{array}$ \\
\hline Audit Quality (AQ) & $\begin{array}{l}A Q=3 \text { if external auditor from big- } 4 \text { audit firms } \\
A Q=2 \text { if external auditor from big- } 4 \text { representative firms in } \\
P a k i s t a n \\
A Q=1 \text { if external auditor is local }\end{array}$ & \\
\hline \multicolumn{3}{|l|}{ Explanatory Variables } \\
\hline $\begin{array}{l}\text { Family Control Companies } \\
\text { (FCF) }\end{array}$ & $\begin{array}{l}\text { "1" if the family member controls the company or '0' otherwise. } \\
\text { Note: "A firm is considered FCF if family members and one } \\
\text { of the family members hold } 20 \% \text { or more shares and holds a } \\
\text { managerial position such as member of board, chairperson or } \\
\text { CEO." }\end{array}$ & Khan et al. (2015) \\
\hline $\begin{array}{l}\text { Family Ownership firms } \\
\text { (FOF) }\end{array}$ & $\begin{array}{l}\text { Proportion of ownership held by family members." } \\
\text { Note: "A firm is considered FOF if family members and one of } \\
\text { the family members hold } 20 \% \text { or more shares" }\end{array}$ & $\begin{array}{l}\text { Tahir, Rehman, Aziz, Ullah } \\
\text { and Iqbal (2017) }\end{array}$ \\
\hline Family CEO (FCEO) & "FCEO = 1 for family CEO, or '0' otherwise" & $\begin{array}{l}\text { Khan et al. (2013), Wang } \\
(2006)\end{array}$ \\
\hline \multicolumn{3}{|l|}{ Control Variables } \\
\hline Leverage (LEV) & "Total long- term debts / total assets" & \multirow{2}{*}{$\begin{array}{l}\text { Tahir, Ullah and Mahmood } \\
\text { (2015) }\end{array}$} \\
\hline Profitability (PR) & "Net earnings / total assets" & \\
\hline $\begin{array}{l}\text { Exports (EX) (Industry } \\
\text { Variable) }\end{array}$ & "EX = ' 1 ' for textile sector firms or '0' otherwise" & $\begin{array}{l}\text { Khan et al. (2013), Khan et } \\
\text { al. (2015) }\end{array}$ \\
\hline
\end{tabular}

\subsection{Econometric Models}

The study typically uses the Ordinary Least Square (OLS) and Probit regression econometric models to calculate the audit fee (AF) and audit quality (AQ) on Family Controlled Firms (FF) and family ownership, respectively.

$$
\begin{gathered}
\mathrm{AF}=\beta_{0}+\beta_{1} \mathrm{FSC}_{i, t}+\beta_{2} \mathrm{AQ}_{i, t}+\beta_{3} \mathrm{FOF}_{i, t}+\beta_{4} \mathrm{FCEO}_{i, t} \\
+\beta_{5} \mathrm{LEV}_{i, t}+\beta_{6} \mathrm{PR}_{i, t}+e_{i, t}
\end{gathered}
$$

$$
\begin{aligned}
& \mathrm{AF}=\beta_{0}+\beta_{1} \mathrm{FCF}_{i, t}+\beta_{2} \mathrm{AQ}_{i, t}+\beta_{3} \mathrm{FC} \times \mathrm{AQ}_{i, t}+\beta_{4} \mathrm{FOF}_{i, t} \\
& +\beta_{5} \mathrm{FCOE}_{i, t}+\beta_{6} \mathrm{LEV}_{i, t}+\beta_{7} \mathrm{PR}_{i, t}+e_{i, t} \\
& \mathrm{AF}=\beta_{0}+\beta_{1} \mathrm{FCF}_{i, t}+\beta_{2} \mathrm{AQ}_{i, t}+\beta_{3} \mathrm{FOF}_{i, t}+\beta_{4} \mathrm{FCEO}_{i, t} \\
& +\beta_{5} \mathrm{LEV}_{i, t}+\beta_{6} \mathrm{PR}_{i, t}+\beta_{7} \mathrm{EX}_{i, t}+\beta_{8} \mathrm{FC} \times \mathrm{EX}_{i, t}+e_{i, t} \\
& \mathrm{AQ}=\beta_{0}+\beta_{1} \mathrm{FCF}_{i, t}+\beta_{2} \mathrm{FOF}_{i, t}+\beta_{3} \mathrm{FCEO}_{i, t}+\beta_{4} \mathrm{LEV}_{i, t} \\
& +\beta_{5} \mathrm{PR}_{i, t}+e_{i, t}
\end{aligned}
$$




$$
\begin{aligned}
A Q= & \beta_{0}+\beta_{1} F C F_{i, t}+\beta_{2} F O F_{i, t}+\beta_{3} F C E O_{i, t}+\beta_{4} L E V_{i, t} \\
& +\beta_{5} P R_{i, t}+\beta_{6} E X_{i, t}+\beta_{7} F C \times E X_{i, t}+e_{i, t}
\end{aligned}
$$

Where; AF: Audit Fees, FCF: Family Control Firm, AQ: Audit Quality, FOF: Family Owned Firm E: Error Term.

\section{Results and Discussions}

This section provides the results of statistical measures, correlation and regression to analyze the interaction of $\mathrm{AQ}$ and AF.

\subsection{Summary Statistics and Multicollinearity}

The results of the statistical measures are provided in Table 3, which shows that the average AF of firms is Rs 8.33 million. The average price of AQ is 1.36 million. The FOF stands at $29.8 \%$, which means that on average, family members own about $30 \%$ of firms. In sample firms, $49.2 \%$ of CEOs are family members. Correlation analysis is used to predict the power of correlation between all variations of the study. Table 4 shows the "Pearson Correlation

Table 3: Statistics of Measures

\begin{tabular}{|l|c|c|c|}
\hline Measure & MV $^{*}$ & MdV $^{* *}$ & SD $^{* * *}$ \\
\hline AF & 8.3295 & 7.3962 & 6.3251 \\
\hline AQ & 1.3621 & 1.0000 & 0.3952 \\
\hline FCF & 0.5889 & 1.0000 & 0.3985 \\
\hline FOF & 0.2985 & 0.3271 & 3.6241 \\
\hline FCEO & 0.4921 & 1.0000 & 0.3540 \\
\hline LEV & 0.5510 & 0.4125 & 0.7124 \\
\hline PR & 0.0594 & 0.0541 & 0.2145 \\
\hline EX & 0.5324 & 1.0000 & 0.0714 \\
\hline
\end{tabular}

Note: "Mean Value, ${ }^{* *}$ Median Value, ${ }^{* * *}$ Standard Deviation
Matrix" for all steps for verifying multidimensionality in data. The FCF, FOF and FCEO have shown negative correlation with $\mathrm{AF}$ and $\mathrm{AQ}$, indicating that the $\mathrm{FF}$ has reduced $\mathrm{AQ}$ and $\mathrm{AF}$. Our results are consistent with Cheng et al. (2020). The maximum correlation between FOF and FCF is -0.253 .

\subsection{Association between FCF, FOF, AF and AQ}

This section presents the results of correlation analysis, OLS regression model and Probit regression economic models. In addition, the remnants of the models pass various tests for abnormality and correlation. In particular, the plots of the residuals' show no concern. Similarly, the White Sandwich and Huber tests do not present violation of any assumption.

The results of OLS regression are reported in Table 5 for models 1,2 and 3 in this study, while R Square for models 1,2 and 3 is $68.19,64.44$ and 63.12 percent, respectively. These models are compared with other studies of developing countries (e.g., Khan et al., 2013; Ahmed \& Goyal, 2005). The study finds a negative impact of FCF on AF with coefficients of FCF in model $1(\beta=-0.1950, p<0.01)$, model $2(\beta=-0.1821, \mathrm{p}<0.01)$, and model $3(\beta=-0.1798, \mathrm{p}<$ $0.01)$. It denotes that $1 \%$ increase in FCF leads to decline AF by approximately 19\%. Similarly, FCEO (Model 1: $\beta=$ $-0.1901, \mathrm{p}<0.01$; Model 2: $\beta=-0.1842, \mathrm{p}<0.01$; Model 3: $\beta=-0.1891, p<0.01)$ are found to be negatively significant. In addition, the study tests the relation between AF and FCF. Again, the negative coefficients in model 4 and model 5 indicate negative association $(-0.4263 \&-0.4633)$ between FCF and AF. Thus, in all three cases, we conclude that $\mathrm{H}_{1}$ i.e., Family-controlled companies (FCF) are less likely to pay higher audit fee to get good quality audit in Pakistan, is supported. The evidences imply that FCF are less likely to demand widespread audit and incur high AF. The arguments are consistent with entrenchment effect and indicate that family dominated firms care less about the interest of minority shareholders.

Table 4: Correlation Analysis

\begin{tabular}{|l|c|c|c|c|c|c|c|c|}
\hline Variables & AF & AQ & FCF & FOF & FCEO & LEV & PR & EX \\
\hline AF & 1 & & & & & & & \\
\hline AQ & -0.098 & 1 & & & & & & \\
\hline FCF & -0.012 & -0.112 & 1 & & & & & \\
\hline FOF & -0.082 & -0.018 & -0.253 & 1 & & & & \\
\hline FCEO & -0.065 & -0.049 & 0.018 & -0.001 & 1 & & & \\
\hline LEV & 0.114 & 0.035 & -0.087 & 0.040 & -0.028 & 1 & & \\
\hline PR & -0.039 & 0.031 & 0.144 & -0.020 & 0.113 & -0.069 & 1 & \\
\hline EX & -0.044 & 0.131 & 0.019 & 0.051 & 0.143 & -0.031 & 0.210 & 1 \\
\hline
\end{tabular}


Table 5: OLS Outcomes: Association between FCF, FOF and AF

\begin{tabular}{|c|c|c|c|c|c|c|}
\hline \multirow{2}{*}{ Variables } & \multicolumn{2}{|c|}{ M-1 (AF) } & \multicolumn{2}{|c|}{ M-2 (AF) } & \multicolumn{2}{|c|}{ M-3 (AF) } \\
\hline & $\mathrm{CV}^{+}$ & $\mathrm{PV}^{\mathrm{tt}}$ & $\mathrm{CV}^{+}$ & $\mathrm{PV}^{\mathrm{tt}}$ & $\mathrm{CV}^{+}$ & $\mathrm{PV}^{\mathrm{tt}}$ \\
\hline Intercept & 5.9211 & $0.0000^{* * *+}$ & 4.3621 & $0.0000^{* * *}$ & 4.9882 & $0.0000^{* * *+}$ \\
\hline FCF & -0.1950 & $0.0021^{* * *}$ & -0.1821 & $0.0001^{* * *}$ & -0.1798 & $0.0000^{+* *+}$ \\
\hline $\mathrm{AQ}$ & 0.0471 & $0.0432^{* *}$ & 0.0395 & $0.0241^{* *}$ & 0.0415 & $0.0201^{* *}$ \\
\hline $\mathrm{FCF} \times A Q$ & --- & --- & 0.0521 & $0.0324^{* *}$ & --- & --- \\
\hline FOF & -0.3512 & $0.0012^{* * * t}$ & -0.3691 & $0.0001^{* * t *}$ & -0.3590 & $0.0034^{*+*}$ \\
\hline FCEO & -0.1901 & $0.0000^{* * * t}$ & -0.1842 & $0.0000^{* * * *}$ & -0.1891 & $0.0000^{*+*}$ \\
\hline LEV & 0.0181 & 0.3271 & 0.1421 & 0.7214 & 0.0621 & 0.8214 \\
\hline PR & 0.0391 & $0.0000^{* * *}$ & 0.0412 & $0.0000^{* * *}$ & 0.0381 & $0.0000^{*+* * *}$ \\
\hline EX & --- & --- & --- & --- & 0.0485 & $0.0415^{* *}$ \\
\hline FCF $\times E X$ & --- & --- & --- & -- & 0.1250 & $0.0000^{* * * *}$ \\
\hline $\mathrm{R}^{2}$ & \multicolumn{2}{|c|}{0.6819} & \multicolumn{2}{|c|}{0.6444} & \multicolumn{2}{|c|}{0.6312} \\
\hline
\end{tabular}

† Coefficient value, †† P value, ${ }^{* * *}$, ${ }^{* *}$ and * show level of significance at $1 \%, 5 \%$ and $10 \%$, respectively.

Table 6: Ordered Probit Outcomes: Association between FCF, FOF and $A Q$

\begin{tabular}{|c|c|c|c|c|}
\hline \multirow{2}{*}{ Variable } & \multicolumn{2}{|c|}{ M-4: AQ } & \multicolumn{2}{|c|}{ M-5: AQ } \\
\hline & $\mathrm{CV}^{\dagger}$ & $\mathrm{PV}^{\mathrm{tt}}$ & $\mathrm{CV}^{\dagger}$ & $\mathrm{PV}^{\mathrm{tt}}$ \\
\hline Intercept & 6.3241 & $0.0000^{* * *}$ & 5.3691 & $0.0000^{*+*}$ \\
\hline FCF & -0.4263 & $0.0000^{*+*}$ & -0.4633 & $0.0019^{*+*}$ \\
\hline FOF & -0.3681 & $0.0041^{* * *}$ & -0.4123 & $0.0121^{\text {w*t }}$ \\
\hline FCEO & -0.1932 & $0.0000^{*+*}$ & -0.2148 & $0.0000^{*+*}$ \\
\hline LEV & 0.4821 & 0.4291 & 0.6325 & 0.3325 \\
\hline PR & 0.2513 & $0.0000^{* * *+}$ & 0.3152 & $0.0000^{*+*}$ \\
\hline EX & --- & --- & 0.3648 & $0.0532^{* * *}$ \\
\hline FCF $\times E X$ & --- & --- & 0.5412 & $0.0125^{* * *}$ \\
\hline $\mathrm{R}^{2}$ & \multicolumn{2}{|c|}{0.6236} & \multicolumn{2}{|c|}{0.6801} \\
\hline
\end{tabular}

† Coefficient value, †† $\mathrm{P}$ value, ${ }^{* * *},{ }^{* *}$ and ${ }^{*}$ show level of significance at $1 \%, 5 \%$ and $10 \%$, respectively.

Similarly, we test the impact of FOF on AF in models 1-3. The Table 5 indicates that the coefficients of FOF (Model 1 : $\beta=-0.3512, p<0.01 ;$ Model 2: $\beta=-0.3691, p<0.01 ;$ Model $3: \beta=-0.3590, p<0.01)$ negative connections between FOF and AF. It means family ownership firms are likely to pay less audit fee as compared to their counterparts.

Table 6 denotes the negation relation between FOF and AQ. Negative coefficient of FOF indicates that as the ownership of family member's increases, they tend to pay less AF. Thus, the study accepts the $\mathrm{H}_{2}$, i.e., Family ownership firms (FOF) are less likely to pay higher audit fee to get good quality audit in Pakistan. The study does not support the alignment effect.
In addition, the study tests the relation between AQ and AF in model 1, model 2 and model 3. The Table 5 indicates the significant positive impact (Model 1: $\beta=0.0471$, $\mathrm{p}<0.05$; Model 2: $\beta=0.0395, \mathrm{p}<0.05$; Model 3: $\beta=0.0415, \mathrm{p}<0.05)$ of AQ on AF. It means that high quality auditors charge high audit fee premium in Pakistan. The study supports the hypothesis $\mathrm{H}_{3}$. Thus, we can say that the positive relation between $\mathrm{AQ}$ and $\mathrm{AF}$ exists.

\section{Conclusions and Implications}

For the past two decades, family firms (FFs) have been growing rapidly in developing economies around the world. In Pakistan, FFs are the backbone of the economy, accounting for $80 \%$ of market capitalization. Thus, this study is useful for the management of companies. The present study concludes that family-owned firms (FOFs) and family-controlled firms (FCFs) have a reciprocal effect in the context of ownership theories. The management of these companies would like to accept low quality audit (AQ) in return for low audit fee (AF). Our results are consistent with Chae, Nakano and Fujitani (2020).

Furthermore, this study concludes that FF's owners are short-sighted and opportunistic who would short-change other stakeholders (Morck, Shleifer \& Vishny, 1988) in order to maximize profits, a practice that lowers the price and increases the risk to firms (Ji \& Yoon, 2020). In addition, this study delivers vital information to industry experts, academicians, practitioners and policy-makers for incorporating a review of the audit policy of FFs.

There are some theoretical and practical implications of this study. First, the study provides insights into family 
business in Pakistan. As it has been concluded, family companies are acting on the impact of this involvement and point out opportunistic managers, executives working in family firms in Pakistan. Increasing internal ownership reduces the quality of the audit. As a result, the risk increases. Second, the study reveals the nature of the family business of emerging economies that are useful to policy-makers in the region in formulating their policies and plans. Third, the study offers practical implications for experts, research scholars and industry experts so that case studies can be used to understand the impact of admissions and alignment. Financial institutions can use the study to analyze the risk of companies lending. Furthermore, this study provides family insights for individuals who are interested in matters related to family CEOs and their performance in the family business.

The study contains some limitations that point to important directions for future investigation. The current study focuses on family firms (FFs) related to food, leather, chemicals, oil and gas, security paper, machinery and steel, cement and construction companies. This study does not take into account small family businesses (SFBs) in these sectors. We strongly support the inclusion of SFBs to generalize results. Second, we suggest that future studies include large data on family and non-family firms from developed and developing countries for comparative analysis to know the implications of entrenchment and alignment effect around the globe.

\section{References}

Ahmed, K., \& Goyal, M. K. (2005). A comparative study of pricing of audit services in emerging economies. International Journal of Auditing, 9(2), 103-116. https://doi.org/10.1111/j.10991123.2005.00236.x

Al-Okaily, J. (2020). The effect of family control on audit fees during financial crisis. Managerial Auditing Journal. [Online], https://doi.org/10.1108/MAJ-12-2018-2114

Ashbaugh, H., \& Warfield, D. T. (2003). Audits as a corporate governance mechanism: evidence from the German market. Journal of International Accounting Research, 2(1), 1-21. https://doi.org/10.2308/jiar.2003.2.1.1

Cascino, S., Pugliese, A., Mussolino, D., \& Sansone, C. (2010). The influence of family ownership on the quality of accounting information. Family Business Review, 23(3), 246-265. https:// doi.org/10.1177/0894486510374302

Chae, S. J., Nakano, M., \& Fujitani, R. (2020). Financial reporting opacity, audit quality and crash risk: Evidence from Japan. Journal of Asian Finance, Economics and Business, 7(1), 9-17. https://doi.org/10.13106/jafeb.2020.vol7.no1.9

Chaney, P. K., Jeter, D. C., \& Shivakumar, L. (2004). Self-selection of auditors and audit pricing in private firms. The Accounting Review, 79(1), 51-72. https://doi.org/10.2308/accr.2004.79.1.51
Chen, C., Yen, G., Fu, C. and Chang, F. (2007), Family Control, Auditor Independence, and Audit Quality: Empirical Evidence from the TSE-Listed Firms (1999-2002). Corporate Ownership and Control, 4(3), 96-110. http://dx.doi.org/10.22495/ cocv4i3p9

Cheng, T. Y., Li, Y.-Q., Lin, Y.-E., \& Chih, H.-H. (2020). Does the Fit of Managerial Ability with Firm Strategy Matters on Firm Performance. Journal of Asian Finance, Economics and Business, 7(4), 9-19. https://doi.org/10.13106/jafeb.2020.vol7. no4.9

Choi, J. H., Kim, J. B., \& Zang, Y. (2010). Do abnormally high audit fees impair audit quality? Auditing: A Journal of Practice \& Theory, 29(2), 115-140. https://doi.org/10.2308/ aud.2010.29.2.115

Del Bosco, B., \& Bettinelli, C. (2020). How Do Family SMEs Control Their Investments Abroad? The Role of Distance and Family Control. Management International Review, 60(1), 1-35. https://doi.org/10.1007/s11575-019-00406-6

Francis, J. (2004). What do we know about audit quality? British Accounting Review, 36(4), 345-368. https://doi.org/10.1016/j. bar.2004.09.003

Gaaya, S., Lakhal, N., \& Lakhal, F. (2017). Does family ownership reduce corporate tax avoidance? The moderating effect of audit quality. Managerial Auditing Journal, 32(7), 731-744. https:// doi.org/10.1108/MAJ-02-2017-1530

Ghosh, A. A., \& Tang, C. Y. (2015). Assessing financial reporting quality of family firms: The auditors' perspective. Journal of Accounting and Economics, 60(1), 95-116. https://doi. org/10.1016/j.jacceco.2015.03.002

Hay, D. (2013). Further evidence from meta-analysis of audit fee research. International Journal of Auditing, 17(2), 162-176. https://doi.org/10.1111/j.1099-1123.2012.00462.x

Ho, J. L., \& Kang, F. (2013). Auditor choice and audit fees in family firms: evidence from the S\&P 1500. Auditing: A Journal of Practice \& Theory, 32(4), 71-93. https://doi.org/10.2308/ ajpt-50533

Homayoon, S., \& Hakimzadeh, M. (2017). Audit Fee and Audit Quality: An Empirical Analysis in Family Firms. International Journal of Economics and Financial Issues, 7(2), 469-476. Retrieved February 17, 2020, from http: www.econjournals. com

Imam, M. O., \& Malik, M. (2007). Firm performance and corporate governance through ownership structure: evidence from Bangladesh stock market. International Review of Business Research Papers, 3(4), 88-110. Retrieved January 14, 2020, from https://ssrn.com/abstract=2256480

Islam, M. A., \& Deegan, C. (2008). Motivations for an organization within a developing country to report social responsibility information: evidence from Bangladesh. Accounting, Auditing \& Accountability Journal, 21(6), 850-874. https://doi. org/10.1108/09513570810893272

Jensen, M. C., \& Meckling, W. H. (1976). Theory of the firm: Managerial behavior, agency costs and ownership structure. 
Journal of financial economics, 3(4), 305-360. https://doi. org/10.1007/978-94-009-9257-3_8

Ji, S.-H., \& Yoon, K.-C. (2020). The Effects of Widening Daily Stock Price Limits on the Relevance between Audit Quality and Stock Return. Journal of Asian Finance, Economics and Business, 7(4), 107-119. https://doi.org/10.13106/jafeb.2020. vol7.no4.107

Joshi, P. L., Al Ajmi, J., \& Bremser, W. G. (2009). A study of auditor-client relationships and problems in the Bahraini audit environment. Advances in Accounting, 25(2), 266-277. https:// doi.org/10.1016/j.adiac.2009.08.003

Karim, A. K. M. W. (2010). Audit pricing, audit concentration and big 4 premium in Bangladesh. [Online] http://dx.doi. org/10.2139/ssrn. 1613454

Khan, A., Muttakin, M. B., \& Siddiqui, J. (2013). Corporate governance and corporate social responsibility disclosures: evidence from an emerging economy. Journal of Business Ethics, 114(2), 207-223. https://doi.org/10.1007/s10551-0121336-0

Khan, A., Muttakin, M. B., \& Siddiqui, J. (2015). Audit fees, auditor choice and stakeholder influence: Evidence from a family-firm dominated economy. The British Accounting Review, 47(3), 304-320. https://doi.org/10.1016/j.bar.2015.03.002

Lei, A. C., \& Lam, S. W. (2018). Family ownership, auditor choice and audit fees: evidence from Hong Kong. In Seventh Asia Pacific Interdisciplinary Research in Accounting Conference in Kobe, Japan on (pp. 26-28).

Leung, S., Wang, R. (2010). Family control, audit committees and audit fees. Corporate Ownership \& Control, 7(3), 73-85. http:// doi.org/10.22495/cocv7i3p6

Liu, L., \& Subramaniam, N. (2013). Government ownership, audit firm size and audit pricing: Evidence from China. Journal of Accounting and Public Policy, 32(2), 161-175. https://doi. org/10.1016/j.jaccpubpol.2012.11.004

Mitra, S., Hossain, M., \& Deis, D. R. (2007). The empirical relationship between ownership characteristics and audit fees. Review of Quantitative Finance and Accounting, 28(3), 257285. https://doi.org/10.1007/s11156-006-0014-7

Mohammad Rezaei, F., Mohd-Saleh, N., \& Ahmed, K. (2018). Audit firm ranking, audit quality and audit fees: Examining conflicting price discrimination views. The International Journal of Accounting, 53(4), 295-313. https://doi. org/10.1016/j.intacc.2018.11.003

Morck, R., Shleifer, A., Vishny, R., (1988). Management ownership and corporate performance: an empirical analysis. Journal of Financial Economics, 20, 293-315. https://doi.org/10.3386/ w2055

Nosheen, S., \& Chonglerttham, S. (2013). Impact of board leadership and audit quality on disclosure quality: Evidence from Pakistan.
International Journal of Disclosure and Governance, 10(4), 311-327. http://dx.doi.org/10.1057/jdg.2013.7

Pakistan Bureau of Statistics (2017-18). Retrieved February 12, 2020, from http://www.pbs.gov.pk/

Rainsbury, E. A., Bradbury, M., \& Cahan, S. F. (2009). The impact of audit committee quality on financial reporting quality and audit fees. Journal of Contemporary Accounting \& Economics, 5(1), 20-33. https://doi.org/10.1016/j.jcae.2009.03.002

Sarhan, A. A., Ntim, C. G., \& Al-Najjar, B. (2019). Antecedents of audit quality in MENA countries: The effect of firm-and country-level governance quality. Journal of International Accounting, Auditing and Taxation, 35, 85-107. https://doi. org/10.1016/j.intaccaudtax.2019.05.003

Shahzad, F., Shahnaz, A., \& JAVID, A. Y. (2017). An investigation of economic consequences of family control and audit quality of firms: a case study of Pakistan. Pakistan Journal of Applied Economics, 27(2), 233-248. Retrieved February 28, 2020, from https://ideas.repec.org/a/pje/journl/article27winv.html

Siddiqui, J., Zaman, M., \& Khan, A. (2013). Do big-four affiliates earn audit fee premiums in emerging markets? Advances in Accounting, 29(2), 332-342. https://doi.org/10.1016/j. adiac.2013.09.007

Sobhan, F., \& Werner, W. (2003). Diagnostic study of existing corporate governance scenario in Bangladesh. A comparative analysis of corporate governance in South Asia: Bangladesh Enterprise Institute. Retrieved January 11, 2020, from http://beibd.org/wp-content/uploads/2015/03/whc4f4bb192762221.pdf

Surya, R. L., \& Fitriany, F. (2019, October). Impact of Family Ownership on the Firm's Abnormal Audit Fees. In 2018 International Conference on Islamic Economics and Business (ICONIES 2018). Atlantis Press.

Tahir, S. H., Rehman, F., Aziz, Q., \& Rizwan, M. Impact of Family Involvement on the Bank Performance and Risk Taking Behavior: Evidence from Islamic Countries. Journal of Managerial Sciences, 11(3), 39-52. Retrieved January 22, 2020, from http://www.qurtuba.edu.pk/jms/11_3.htm

Tahir, S. H., Ullah, M. R., \& Mahmood, S. (2015). Banks dividend policy and investment decision as determinants of financing decision: Evidence from Pakistan. American. Journal of Industrial and Business Management, 5(5), 311-323. http:// dx.doi.org/10.4236/ajibm.2015.55032

Wang, D. (2006). Founding family ownership and earning quality. Journal of Accounting Research, 44(3), 619-656. https://doi. org/10.1111/j.1475-679X.2006.00213.x

Yopie, S., \& Itan, I. (2016). CEO-Family vs. CEO-Nonfamily: Who is a Better Value Creator in Family Business? Journal of Applied Management Accounting Research, 14(2), 37-41. Retrieved February 21, 2020, from http:/www.cmawebline. org/ontarget/wp-content/uploads/2017/01/JAMARv14.2-CEOin-Family-Business.pdf 